\title{
Morphometrics and genetic diversity of Tegal, Magelang and their crossbred ducks based on Cytochrome b gene
}

\author{
Henrik $^{1, *}$, D. Purwantini ${ }^{2}$ and Ismoyowati ${ }^{2}$ \\ ${ }^{1}$ College of Agriculture of Mujahidin Tolitoli, \\ Jl. Dr. Samratulangi No. 51 Tuweley, Tolitoli, Central Sulawesi 94515 - Indonesia \\ ${ }^{2}$ Animal Science Faculty, University of Jenderal Soedirman, \\ Jl. Dr. Soeparno No. 60 Purwokerto-Central Java 53122 - Indonesia \\ *CorrespondingE-mail : hendrikaprawi@gmail.com
}

Received June 26, 2017; Accepted February 06, 2018

\begin{abstract}
ABSTRAK
Penelitian ini bertujuan untuk mengetahui keragaman morfometrik dan genetik itik Tegal, Magelang, dan hasil persilangannya. Masing-masing 10 ekor itik betina Tegal, Magelang, Gallang, dan Maggal yg berumur 20 minggu digunakan sebagai kelompok materi penelitian. Morfometrik yang diukur adalah bobot badan, lingkar dada, panjang badan, panjang shank, panjang leher, dan lebar pubis. Data yang diperoleh dianalisis menggunakan analisis variansi klasifikasi satu arah. Untuk mengetahui polimofisme gen Cytochrome b (cyt b) DNA mitokondria digunakan Polymerase Chain ReactionRestriction Fragment Length Polymorphism (PCR-RFLP). Jarak genetik dianalisis berdasarkan nilai heterozigositas, sedangkan pohon filogeni direkonstruksi menggunakan software MEGA 6. Hasil penelitian menunjukkan terdapat perbedaan yang sangat nyata $(\mathrm{P}<0.01)$ pada bobot badan, lingkar dada, panjang badan, dan panjang leher antar kelompok, sedangkan panjang shank dan lebar pubis tidak berbeda nyata. Jarak genetik antara itik Gallang dengan Maggal (0.206) lebih tinggi dibanding itik Tegal dengan Magelang (0.169). Berdasarkan hasil penelitian dapat disimpulkan bahwa persilangan resiprok meningkatkan keragaman morfometrik dan keragaman genetic itik lokal Indonesia.

Kata kunci: keragaman morfometrik, keragaman genetic, persilangan resiprokal, itik lokal, cytochrome b
\end{abstract}

\begin{abstract}
This experiment was conducted to study the morphometric and genetic diversity of Tegal, Magelang, and their crossbred ducks. Each ten female about twenty weeks old ducks from Tegal, Magelang, Gallang, and Maggal ducks, respectively, were used as the group materialss. The body weight, chest circumference, body length, shank length, neck length, and pubis width were recorded and tested by analysis of variance of one way classification as the morphometric characteristics. Polymorphism of cytochrome $b$ (cyt b) gene on mitochondrial DNA (mtDNA) was analyzed by Polymerase Chain Reaction-Restriction Fragment Length Polymorphism (PCR-RFLP). Genetic distance was analyzed based on value of heterozygosity, whereas the phylogeny tree was reconstructed using MEGA6 software. The results showed there were highly significant difference $(\mathrm{P}<0.01)$ on body weight, chest circumference, body length, and neck length between population, while shank and pubis width were not significant different. The genetic distance between Gallang and Maggal ducks (0.206) was higher than Tegal and Magelang ducks (0.169). It is concluded that the reciprocal crosses increased the morphometric and genetic diversity of Indonesian local duck population.
\end{abstract}

Keywords: korphometric diversity, genetic diversity, reciprocal crosses, local duck, cytochrome b 


\section{INTRODUCTION}

Domestic duck play an important role in animal protein supply (Sultana et al., 2016), which has a high genetic diversity if compared to other populations spread in this world. South-East Asian duck population were closely related to the mallard duck (Anas platyrhynchos) that indicated by their mean overall genetic distance. Indonesian domestic ducks has a relatively closed genetic relationship with Anas Platyrhynchos and Anas zonorhyncha as shown by the variation of the genetic distance ranged from 0.000 to 0.786 (Purwantini et al., 2013a).

The Indonesia local ducks have the morphological features typically. Especially in Central Java province, there were Tegal and Magelang ducks having a high genetic diversity due to extensive raising system and the high egg production which spread almost throughout the territory of Indonesia (Purwantini et al., 2013b; Ismoyowati and Purwantini, 2013; Purwantini and Roesdianto, 2001). Hetzel and Gunawan (1984) stated that Tegal duck lays more eggs and more profitable than Alabio x Tegal crossbred ducks under extensive husbandry. Egg production of Tegal and Magelang dukcs were $70.89 \%$ and $70.24 \%$ with a body weight $1.400 \pm 0.14$ and $1.600 \pm 0.16 \mathrm{~g}$, respectively (Ismoyowati and Purwantini, 2013; Hetzel and Gunawan, 1984). Therefore, both of crossbred's different characteristic or genetic distance may be occurred as the results of reciprocal crosses between Tegal and Magelang ducks.

Warwick et al. (1995) stated that the results of crosses between different strains or species produced the offspring that are better than their parent. The crossbreeding of two strains of duck is expected to produce better offspring without damaging their genetic sequence. Sudewo (2005) reported that if between breeds that has genetic distance $<0.025$, then the crossing between the same breeds will damage the genetic sequence in the population by the inclusion of recessive genes. Therefore, information about genetic distance between duck population is important for duck breeding system. One method often used to determine the genetic distance and relationship is Polymerase Chain Reaction-Restriction Fragment Length Polymorphism (PCR-RFLP).

The PCR-RFLP method in the region of mitochondrial DNA (mtDNA) is a basic technique that is often used in the identification of genetic distance and genetic diversity (Kalita, 2015). The
PCR-RFLP on the cytochrome $b$ of mitochondrial DNA (cyt $b$ mtDNA) is an appropriate method for species identification. PCR-RFLP is also easier and simpler to apply (Kalita, 2015; Minarovic et al., 2010; Chen et al., 2012; Farag et al., 2015). By using cyt $b$ mtDNA, there is no recombination of DNA occur and all offspring from the female parent would have imilarity in mtDNA sequence (Linacre and Tobe, 2011).

In Indonesia, PCR-RFLP method successfully identified the genetic diversity of Indonesian local duck population, those were Magelang, Tegal, Mojosari, Bali and Alabio ducks based on polymorphism of mtDNA D-loop (Purwantini et al., 2013b). Genetic diversity is important for duck breeding management as well as the morphometric diversity. According to Yakubu and Ugbo (2011), the morphometric and genetic diversity are crucial to the development of duck breeding program appropriate in each country. Genetic diversity is also useful for longterm breeding programs such as genetic mapping and molecular breeding marker-based (Kalita, 2015).

Tegal ducks and Magelang ducks had the genetic distance ranged from 0.009 to 0.691 based on the Single Nucleotide Polymorphism (SNP) analysis on the D-loop mtDNA region (Purwantini et al., 2013a). Nevertheless, information about the genetic diversity of Tegal, Magelang, and their crossbred by PCR-RFLP based on polymorphism of $c y t b \mathrm{mtDNA}$ has still limited. Therefore, this experiment was conducted to investigate the morphometric and genetic diversity of Tegal, Magelang, and their crossbred based on polymorphism mtDNA $c y t \quad b$ by PCR-RFLP analysis.

\section{MATERIALS AND METHODS}

\section{Resiprocal Crosses and Morphometric Traits Measurement}

This experiment was conducted at the Experimental Farm of Animal Husbandry Faculty of Jenderal Soedirman University. Forty-four about twenty weeks old duck raised intensively in litter cage, consisting respectively 10 female of Tegal ducks, Magelang, Gallang and Maggal ducks, and 2 male ot Tegal and Magelang ducks, respectively. The crossbred of Tegal male duck and Magelang female duck called the Gallang ducks, while crossbred of Magelang male duck and Tegal female duck called the Maggal duck. The equipments used were litter cage, feed tray, 
drinking water, hatching machine, egg tray, shovels, hoses, buckets, stationery, thermometer, hygrometer, binocular eggs, weigher analytic, sprayer, and tape meter. Starter feed (BR1) was given by continuously with $21 \%$ Crude Protein (CP) and $3100 \mathrm{kcal} / \mathrm{kg}$ Metabolic Energy (ME). The grower duck (four-week-old ducks) was fed $100 \mathrm{~g} /$ day of diet increased up to $150 \mathrm{~g}$ at eightweeks-old. The grower feed was composed of $30 \%$ corn, $20 \%$ of laying concentrate, $50 \%$ rice bran that containing $15.07 \% \mathrm{CP}, 2806 \mathrm{kcal} / \mathrm{kg}$ ME, 1.8\% Calcium (Ca), and 1.22\% Phosphor (P). On the layer phase, the feed given was 160 g/duck/day consisting of $20 \%$ corn, $16.7 \%$ of laying concentrate, $63.3 \%$ rice bran that containing $16.95 \% \mathrm{CP}, 2884 \mathrm{kcal} / \mathrm{kg} \mathrm{ME}, 0.56 \%$ $\mathrm{Ca}$, and $0.97 \mathrm{P}$, while drinking water was provided by continuously.

The observed variables were body weight, chest circumference, body length, shank length, neck length, and pubis width. Figure 1. shows method to measure body measurement. Morphometric was measured during one week when duck start to production (Ismoyowati et al., 2006). Body length (BL) was measured between the lengths of the end rostrum maxilla until the tail section. Chest circumference (CC) was measured in the area under the wings at the edge of the sternum. Neck length (NL) was measured from the occipital condyles and cephalic limits on coracoids. Shank length (SL) bone was measured by the length of metatarsus (Teguia et al., 2008) while pubis width (PW) was measured by the distance between left and right pubis (Ismoyowati et al., 2006). Data were analyzed using an analysis of variance of one way classification with mathematical models by Gomez and Gomez (1984).

\section{Polymorphism of Cytochrome b Gene of Mitochondrial DNA}

Blood sample was taken from ten female each of Tegal, Magelang, Gallang, and Maggal ducks, respectively. The materials used in the laboratory were disposyble syrink, micropipette, blue type, yellow type, white type, epppendorf, water bath, microwave, gloves, thermo cycler machine Advance Primus 25 (PEQLAB, Erlangen, Germany), submarine electrophoresis (Z372331 model, Sigma-USA), UV visualization (Z654469 model, Sigma-USA), DNA isolation kit (GENEAID), PCR kit, good view, agarose powder, TBE buffer, ethanol absolute, loading day, restriction enzyme (HaeIII), Phosphate
Buffer Saline (PBS), dH2O, Primer forward (5'TGCAACCCCAGTCCTAGTC-3'), and Primer reserve (3'-GAAGGCTAGGATTTT GCGTGT$\left.5^{\prime}\right)$.

\section{Isolation of DNA and Amplification}

The steps of DNA isolation was based on the instructions of DNA isolation kit. Amplification of DNA was performed by using a thermo cycler machine on the cyt $b$ mtDNA using forward primer (TGCAACCCCAGTCCTAGTC 5'-3'), and reserve primer (GAAGGCTAGGATTTT GCGTGT-3'-5'). The design of oligonucleotide specific primer of cytochrome $b$ gene was performed on the basis of the database of GeneBank EU678239.1 (He et al., 2008). The primary pair was selected on the conserve area, analyzed by the Design Oligoprimer Software with the Primer3 online program. Polymerase chain reaction was performed with the cyt $b$ mtDNA target gene in $25 \mu \mathrm{L}$ total reaction volume that consisting 12,5 $\mu \mathrm{L}$ KAPA2G Fast Ready Mix PCR Kit (Kapa Biosystems), 9.5 $\mu \mathrm{L}$ $\mathrm{dH}_{2} \mathrm{O}, \quad 1 \mu \mathrm{L}$ forward and reverse primer respectively, and $1 \mu \mathrm{L}$ of DNA template. The stage of pre-denaturation was performed for 5 minutes at $94^{\circ} \mathrm{C}$. Furthermore, denaturation stage was carried out at $94^{\circ} \mathrm{C}$ for 30 seconds and was followed by annealing at $55^{\circ} \mathrm{C}$ for 45 seconds. The stage where the elongation of the PCR reaction will be discontinued, thermo cycler conditions maintained at $72^{\circ} \mathrm{C}$ for 1 minute. The last stage of the PCR reaction is post-elongation. It is the stage of DNA elongation reaction to enhance and was performed for 5 minutes at $72^{\circ} \mathrm{C}$. The PCR reaction repeated for 35 cycles. Furthermore, the PCR product were separated by electrophoresis in $1.5 \%$ low-melting agarose gel using 0,5 TBE buffer in electrophoresis machine Power PAC 3000 (BIO PAD).

\section{Restriction Fragment Length Polymorphism}

Restriction Fragment Length Polymorphism was performed on PCR products using endonuclease restriction enzyme HaeIII for 6 hours at $37^{\circ} \mathrm{C}$ consisting of $1 \mu \mathrm{L}$ restriction enzyme HaeIII, $2 \mu \mathrm{L}$ of buffer enzyme, $7 \mu \mathrm{L}$ of $\mathrm{dH} 2 \mathrm{O}$, and $5 \mu \mathrm{L}$ of PCR product. The reason for using this enzyme was because of easy to obtain and has four site cuts on the primer were used. The results of this digestion then electrophoreses on $2 \%$ agarose gel and visualized using ultraviolet light. 


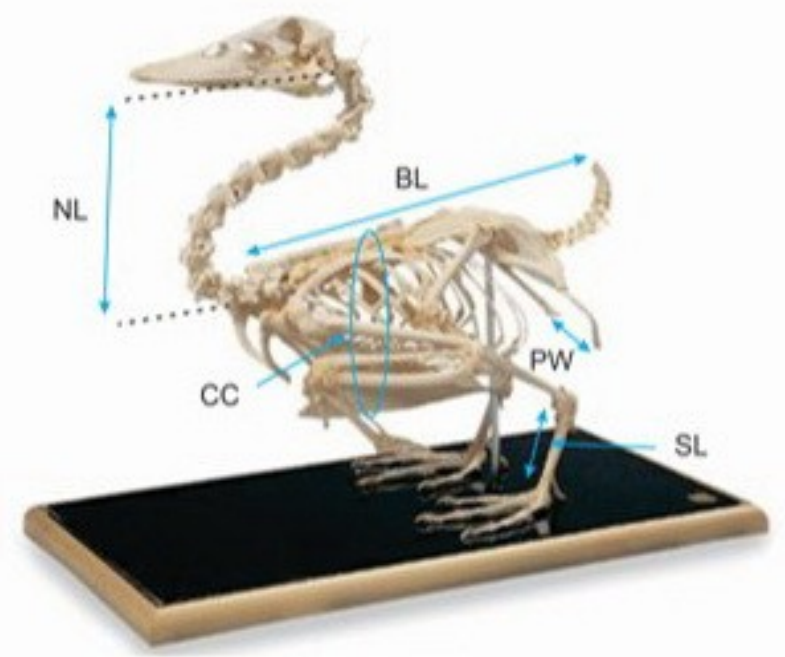

Figure 1. Measurement Method of Morphometric of Duck (modified from http: www.anatomywarehouse.com). NL: neck length; BL: body length; CC: chest circumference PW: pubis width; SL: shank length

\section{Data Analysis}

Fragment patterns of mtDNA cyt $b$ as the digestion results using the restriction enzyme HaeIII was tabulated to determine haplotypes. The different of paterns of DNA band was showed on agarose gel, then was used to determine haplotype, gen frequency, heterozygosity, and genetic distance. The genetic frequency was determined by Pirchner's formula (Pichner, 1981):

$$
\mathrm{F}_{\mathrm{An}}=\frac{\sum \text { locus }_{\mathrm{An}}}{\sum \operatorname{locus}_{\mathrm{A} 1}+\sum \operatorname{locus}_{\mathrm{A} 2}+. .+\sum \text { locus }_{\mathrm{An}}}
$$

where:

$\mathrm{F}_{\mathrm{An}}$ is frequency $\mathrm{A}^{\text {th }}$ gene at the $\mathrm{k}^{\text {th }}$ locus. Based on frequency of gene, individual heterozigosity was determined by Nei's formula (Nei, 1978):

where:

$$
\mathrm{h}=1-\sum \mathrm{p}_{\mathrm{i}}^{2}
$$

$p_{i}$ is the frequency of $i^{\text {th }}$ allele at locus in the population. Individual heterozigosity (h) is the value that describes genetic diversity in the population, whereas average heterozygosity $(\mathrm{H})$ was defined as the mean value of over all loci in the genome. Value for single loci was estimated using unbiased estimate by Nei's formula (Nei, 1978):

where:

$$
h_{i}=2 n\left(1-\sum x_{i}^{2}\right) /(2 n-1)
$$

$\mathrm{X}_{1}$ is frequency of corresponding allele in a sample from the population, value of $\mathrm{n}$ individual can be different every loci. The average heterozygosity $(\mathrm{H})$ was estimated by Nei's formula (Nei, 1978):

$$
\mathrm{H}=\sum_{\mathrm{k}=1}^{\mathrm{r}} \frac{\mathrm{h}_{\mathrm{i}}}{\mathrm{r}}
$$

where:

$h_{i}$ as $h$ value at $i^{\text {th }}$ loci. Individual heterozigosity (h) is the value that the genetic distance was estimated by Nei's formula (Nei, 1978):

$$
\mathrm{D}=-\ln \left[\frac{\mathrm{G}_{\mathrm{xy}}}{\sqrt{\mathrm{G}_{\mathrm{x}} \mathrm{G}_{\mathrm{y}}}}\right]
$$

where:

$G_{x}$ is the mean of $\sum p_{i}^{2}, G_{y}$ is the mean of $\sum q_{i}^{2}$, and $G_{x y}$ is the mean of $\sum p_{i} q_{i}$ over all loci in the genome. Relationship genetic between population was reconstructed using MEGA 6.06 (build number: 6140226) software with UPGMA method (Tamura et al., 2013).

\section{RESULTS AND DISCUSSION}

\section{Morphometric Characteristics}

Based on the anova of one way classification, the difference among duck population showed highly significant effect $(\mathrm{P}<0.01)$ on body weight, chest circumference, body length, and neck length, whereas the shank 
length and pubis width were not significantly different. The body weight of Gallang and Maggal ducks highly significant different $(\mathrm{P}<0.01)$ compared to Tegal and Magelang ducks, while between the Gallang and Maggal duck was not significant different. The body weight of Magelang ducks was higher than Tegal ducks (Table 1), in which the previous study were $1.660 \pm 0,16 \mathrm{~g}$ and $1.400 \pm 1.550 \mathrm{~g}$, respectively for Magelang and Tegal duck (Hetzel and Gunawan, 1984; Ismoyowati et al., 2006). The different of body weight in this study was due to genetic factors because environmental effects has been made uniformly. Ismoyowati et al. (2006) reported that when the affects of the environment are uniform, phenotypes that appear will showed the genetic capability. According to Yakubu and Ugbo (2011), comparison of phenotype based on morphological characteristics could be representing of genetic differences.

The body weight of Magelang ducks was higher $(\mathrm{P}<0.01)$ than others ducks in this experiment (Table 1). The body weight of Gallang and Maggal ducks was also higher $(\mathrm{P}<0.01)$ than Tegal ducks, but there was no significant different between Gallang and Maggal ducks. These different may be influenced by additive genetic inherited from their parent that was called maternal effect. Szwaczkowsk et al. (2010) reported that the affect of the parent is defined as all of the affect of the parent to offspring, including direct and genetic affect. Body weight is a complex phenotypic with single loci considered as influential, in which presence of dominant genes will give effect to quantitative characteristics including body weight. As well as the heritability $\left(h^{2}\right)$, genetic additive has a very significant influence on the quantitative characteristics of ducks (weight, length of the sternum, and the thickness of the chest muscles).

The variation of morphometric characteristics appearance among Tegal, Magelang, Gallang, and Maggal ducks was not only on body weight but also in other morphometric. The chest circumference size of Magelang ducks was higher $(\mathrm{P}<0.01)$ than that of Tegal duck, but there was no significant different between Gallang and Maggal ducks. Body length and neck length of Gallang and Maggal ducks was higher $(\mathrm{P}<0.01)$ than that of Magelang and Tegal ducks, but there was no significant different between body length of Gallang and Maggal ducks. Neck length of Maggal ducks was higher $(\mathrm{P}<0.01)$ than the others ducks in this experiment. Shank length and pubis width were not significant different over all duck population in this study.

Cytochrome $b$ mtDNA play an important role in cell respiration to provide energy for metabolism, involved in trans-membrane electron transfer, as well as a center for catalytic subunit ubiquinol-cytochrome c-reductase (complex III) which is an enzyme involved in the respiratory chain reaction (Esposti et al., 1993; McDonald et al., 2010; Rich and Maréchal, 2010; Heiske, 2010). The number of mitochondria varies greatly between different organisms and even between tissues within the same organism (Esposti et al., 1993; Rich and Marechal, 2010).

Table 1. Average Morphometric Characteristics of Tegal Ducks, Magelang Dcks, and Their Crossbred

\begin{tabular}{lcccc}
\hline \multirow{2}{*}{\multicolumn{1}{c}{ Characteristic }} & \multicolumn{4}{c}{ Duck } \\
\cline { 2 - 5 } & Magelang & Tegal & Gallang & Maggal \\
\hline Body weight $(\mathrm{g})$ & $1659 \pm 200^{\mathrm{a}}$ & $1196 \pm 94^{\mathrm{d}}$ & $1408 \pm 153^{\mathrm{bc}}$ & $1469 \pm 177^{\mathrm{b}}$ \\
Chest circumference (cm) & $30.55 \pm 1.38^{\mathrm{a}}$ & $28.45 \pm 0.69^{\mathrm{bc}}$ & $29.75 \pm 1.31^{\mathrm{ab}}$ & $29.29 \pm 1.38^{\mathrm{ab}}$ \\
Body length (cm) & $20.75 \pm 0.79^{\mathrm{b}}$ & $18.80 \pm 0.63^{\mathrm{c}}$ & $23.38 \pm 0.68^{\mathrm{a}}$ & $23.67 \pm 0.70^{\mathrm{a}}$ \\
Shank length (cm) & $6.45 \pm 0.49$ & $6.10 \pm 0.46$ & $6.23 \pm 0.33$ & $6.08 \pm 0.07$ \\
Neck length (cm) & $17.70 \pm 1.54^{\mathrm{c}}$ & $16.60 \pm 1.24^{\mathrm{cd}}$ & $21.50 \pm 1.13^{\mathrm{b}}$ & $23.30 \pm 0.87^{\mathrm{a}}$ \\
Pubis width (cm) & $5.90 \pm 0.63$ & $5.70 \pm 0.39$ & $6.23 \pm 0.34$ & $6.16 \pm 0.32$ \\
\hline
\end{tabular}

* Marked fields with a different letter notation in the same row means significantly different based on the $1 \%$ level of HSD test. 
The interaction among genes may be one factor that can affect the raising a new phenotype on the crossbred duck population. Suryo (2005) stated that appearing of a new phenotype on the offspring was the results of a crossbreeding. The appearing of variation on morphometric characteristics of Gallang and Maggal duck was the result of the reciprocal crosses may be affected by the interaction of genes, as well as by maternal genetic including the mitochondria. Body weight and other morphometric characteristic are quantitative traits (Szwaczkowski et al., 2010) that involved one more gene or many genes.

\section{Polymorphisms of Cytochrome b and Genetic Distance}

The mtDNA Cyt b was isolated and has a size of 533 base pairs (bp) of PCR product. Based on PCR-RFLP method, this experiment showed the polymorphism in the mtDNA cyt $b$ gene of Tegal, Magelang, Gallang, and Maggal ducks. Restriction patterns were discovered by HaeIII restriction enzyme were 533 bp, 284 bp, 174 bp, and 75 bp respectively (Figure 2). There were four haplotypes based on restricting patterns. On Tegal and Magelang ducks were two haplotypes (A and C), Gallang ducks three haplotypes (B, C, and D), as well as Maggal ducks has four haplotype, those were A, B, C and D (Table 2). These proven the genetic diversity of domestic duck population in Indonesia were previous reported (Purwantini et al., 2013b).

Purwantini et al. (2013b) reported that 6 haplotype (A, B, C, D, E, and F) of Indonesia local duck population (Magelang ducks, Tegal ducks, Mojosari ducks, Bali ducks, and Alabio ducks) on the basis of polymorphism of mtDNA D-loop gene. The difference on the number of haplotypes was founded may due to several factors including the restriction enzyme type and DNA region was used. Purwantini et al. (2013b) reported that D-loop of mitochondrial DNA region has highly polymorphism degree in the mitochondrial genome. However, mtDNA $c y t b$ gene still recommended as a universal primers for the species identification study by PCR-RFLP because it has stable sequences (Minarovic et al., 2010).

On the basis of the value of heterozygosity (h), genetic diversity of duck population in this study was about 0658-0691 (Table 3). It means, there was no recombination occur in mtDNA cyt $b$ gene. According to Linacre and Tobe (2011), all the offspring of their mother would have identical sequences of mtDNA, except mutations occurred. Wu et al. (2008) reported that low levels of genetic diversity of a population showed that

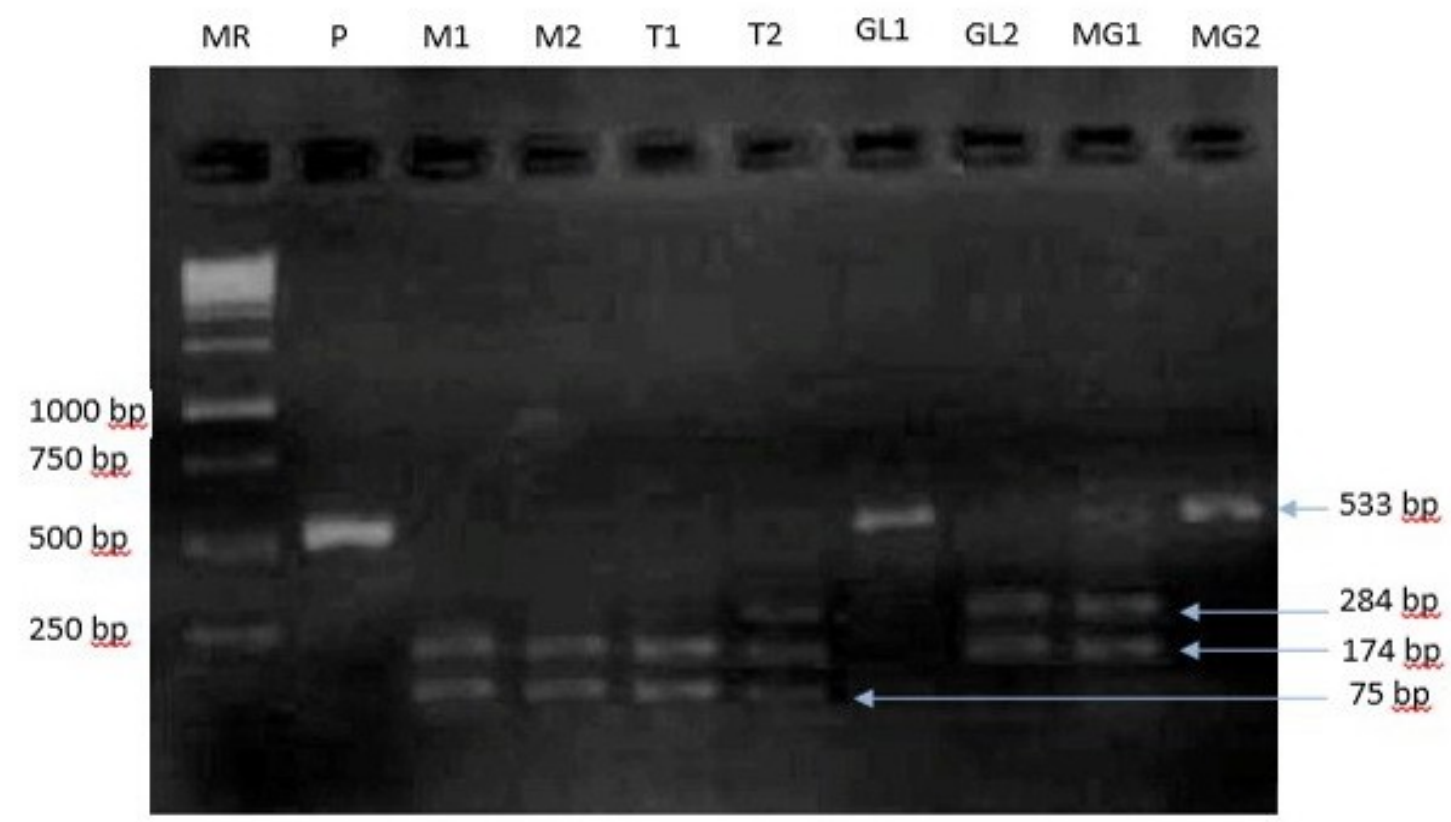

Figure 2. The fragment patterns of $c y t b$ mtDNA using HaeIII restriction enzyme. MR (Marker), P (PCR product), M (Magelang ducks), T (Tegal ducks), GL (Gallang ducks), and MG (Maggal ducks) 
Table 2. The Haplotype of Tegal Ducks, Magelang Ducks, and Their Crossbred by PCR-RFLP with HaeIII Restriction Enzyme

\begin{tabular}{lcccc}
\hline \multirow{2}{*}{ Ducks } & \multicolumn{4}{c}{ Haplotype } \\
\cline { 2 - 5 } & A (75 and 174 bp) & B (174 and 284 bp) & C (75, 174, and 284 bp) & D (533 bp) \\
\hline Tegal & 3 & - & 7 & - \\
Magelang & 2 & - & 8 & - \\
Gallang & - & 1 & 8 & 1 \\
Maggal & 1 & 1 & 7 & 1 \\
\hline
\end{tabular}

there is no genetic mutations occur or the possibility of genetic mutation is very small. It is also in conformity with the average value of average heterozygosity $(\mathrm{H})$ over all duck population in this study showing very small and closely to $0(0.0273 \pm 0.0013)$ and this may indicate the very small possibility of a genetic drift.

The changes of gene frequencies that occur were also very small, so there was not significant increase of $h$ value. Mulliadi and Arifin (2010) reported that the changes of gene frequencies that occur in the DNA had a role to raising the value of heterozygosity. Inbreeding crosses could decrease $h$ value while outbreeding crosses could increase it. Therefore, reciprocal crosses in this study indicated no inbreeding occur. It was proved by increasing the $\mathrm{h}$ value on the crossbred duck population. Instead, the reciprocal crosses could increased the genetic diversity in accordance with the report of Su et al. (2006) on duck population in China.

Kalita (2015) stated that genetic diversity is a combination of genes founded in a population and different patterns of variation across population in the same species. The genetic distance across duck population founded in this study showed genetic diversity. The genetic distance between Tegal and Magelang duck population closer than genetic distance between Gallang and Maggal duck (Table 4). The genetic distance between Tegal and Magelang duck in this study according to the previous study was reported by Purwantini et al. (2013a) about 0.009-0, 691 based on D-loop mtDNA region. Gallang and Maggal ducks as the offspring of reciprocal crosses has a similarity and relationship tend to be closer to Tegal ducks compared with Magelang ducks.
Table 3. Value of Individual Heterozygosity (h) and the Average Heterozygosity $(\mathrm{H})$ on the Tegal Ducks, Magelang Ducks, and Their Crossbred Duck Population

\begin{tabular}{ll}
\hline \multicolumn{1}{c}{ Duck } & Heterozygosity \\
\hline Tegal $(\mathrm{T})$ & $0.658 \pm 0.089 \mathrm{~h}$ \\
Magelang (M) & $0.633 \pm 0.086 \mathrm{~h}$ \\
Gallang (GL) & $0.690 \pm 0.078 \mathrm{~h}$ \\
Maggal (MG) & $0.691 \pm 0.037 \mathrm{~h}$ \\
\hline
\end{tabular}

$\mathrm{H}=0.0273 \pm 0.0013$

On the basis of phylogeny tree, Tegal and Magelang ducks were in the same cluster that described a very close relationship, while Gallang and Magal duck in a different cluster (Figure 3). Relationship of Maggal ducks is closer to Tegal and Magelang ducks cluster, while Gallang ducks was outside of the cluster. It means Gallang ducks has a further genetic relationship with other duck population in this study. Although, the length branch of cluster has appeared was very small indicates no genetic mutation occur. Blanchette et al. (2012) stated that small branch distance between clusters was due there was no genetic mutation occurs.

The genetic distance raised by reciprocal crosses between Tegal and Magelang ducks can increase the genetic diversity of domestic duck population in Indonesia. However, the morphometric and genetic diversity of crossbred of Gallang with Magelang duck or Maggal with Tegal duck has not identified. Because, this study is limited only to find out the morphometric and 
Table 4. Genetic Distance of Tegal Ducks, Magelang ducks, and Their Crossbred Population Based on PCR-RFLP Analysis on $c y t b$ mt-DNA

\begin{tabular}{lcccc}
\hline \multirow{2}{*}{ Duck } & \multicolumn{3}{c}{ Genetic Distance between Population } \\
\cline { 2 - 5 } & Tegal & Magelang & Gallang & Maggal \\
\hline Tegal & 0 & 0.169 & 0.186 & 0.186 \\
Magelang & & 0 & 0.189 & 0.189 \\
Gallang & & 0 & 0.206 \\
Maggal & & & 0 \\
\hline
\end{tabular}

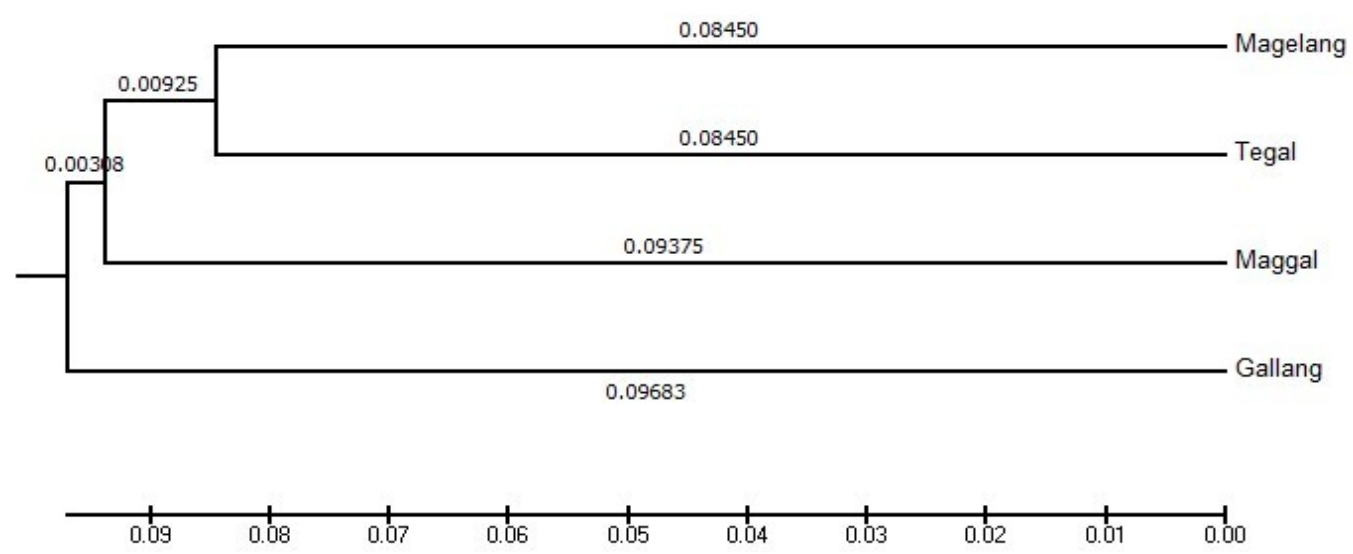

Figure 3. Phylogeny Tree of Tegal ducks, Magelang ducks, and Their Crossbred Based on UPGMA Method using MEGA 6 Software

genetic diversity within Tegal and Magelang ducks population as well as their crossbred. Therefore, more research is needed to identifying the morphometric and genetic diversity of "backcross-offspring" with their parent on Indonesian domestic duck population.

\section{CONCLUSION}

Morphometric and genetic diversity of Tegal ducks, Magelang, Gallang, and Maggal ducks population were obtained by reciprocal crosses in this study. Polymorphism of mitochondria cytochrome $b$ gene can be used to identify genetic diversity of local ducks population in Indonesia.

\section{REFERENCES}

Blanchette, G.R., O'Keefe, and L. Benuskova. 2012. Inference of a phylogenetic tree: hierarchical clustering versus genetic algorithm. Lecture Notes in Computer Science. 7691:300-312.

Chen, S., Y. Yao and Y. Liu. 2012. Species identification of ten common farm animals based on mitochondrial 12S rRNA gene polymorphism. Anim. Biotec, 23:213-220.

Esposti, M.D., S. D. Vries, M. Criml, A. Ghelh, T. Patarnello and A. Meyer. 1993. Mitochondrial cytochrome b: evolution and structure of the protein. Biochem. Biophys. Acta. 1143:243-271.

Farag, M.R., T.S. Imam, and K. Dhama. 2015. Identification of some domestic animal species (camel, buffalo, and sheep) by PCRRFLP analysis of the mitochondrial chytochrome b gene. Adv. Anim. Vet. Sci. 2(3):136-142.

Gomez, K.A. and A.A. Gomez. 1984. Procedure Statistics for Agricultural Research. $2^{\text {nd }} E d$. 
John Willey and Sons, New York.

He, D.Q., Q. Zhu, S.Y. Chen, H.Y. Wang, Y.P. Liu and Y.G. Yao. 2008. A homogenous nature of native Chinese duck matrilineal pool. BMC Evol. Biol. 8:298.

Heiske, M. 2012. Modeling the Respiratory Chain and the Oxidative Phosphorylation. Dissertation. Humboldt-Universitat zu Berlin.

Hetzel, D.J.S. and B. Gunawan, 1984. Egg production of Indonesian native ducks under intensive and extensive conditions. Trop. Anim. Health Prod. 9: 203-215.

Ismoyowati and D. Purwantini. 2013. Produksi dan kualitas telur itik lokal di daerah sentra peternakan itik. J. Pembangunan Pedesaan. 13(1):11-16.

Ismoyowati, T. Yuwanta, J.P.H. Sidadolog and S. Keman. 2006. Relationship between morphological characteristics and reproductive performance of Tegal duck as the basis selection. J. Indonesian Trop. Anim. Agric. 31(3):152-156

Kalita, D.J. 2015. Genetic diversity: Its importance and analysis in animals. Int. J. Res. Emerging Sci. Technol. 2(6):68-72.

Linacre, A. and S.S. Tobe. 2011. An overview to the investigative approach to species testing in wildlife forensic science. Biomed Central. 2(2):1-9.

McDonald, P., R.A. Edwards, J.F.D. Greenhalgh, C.A. Morgan, L.A. Sinclair, and R.G. Wilkinston. 2010. Animal Nutrition. Seventh Edition. Pearson.

Minarovic, T., A. Trakovicka, A. Rafayova, and Lieskovska. 2010. Animal species identification by PCR-RFLP of cytochrome b. Anim. Sci. Biotech. 43(1):296-299.

Mulliadi, D. dan J. Arifin. 2010. Pendugaan keseimbangan populasi dan heterozigositas menggunakan pola protein albumin darah pada populasi Domba Ekor Tipis (Javanese Thin Tailed) di Daerah Indramayu. J. Ilmu Ternak. 10(2):65-72.

Nei, M. 1978. Estimation of average heterozygosity and genetic distance from a small number of individuals. Genetics. 89:583-590.

Pichner, F. 1981. Population Genetic and Animal Breeding. W.H. Freeman and Co. San Francisco.

Purwantini, D. And Roesdiyanto. 2001. Kinerja Entik Hasil Persilangan (Entog dan Itik) melalui Inseminasi Buatan (IB) yang
Dipelihara Secara Intensif. Jurnal Animal Production. 3(1): 31-39

Purwantini, D., T. Yuwanta., T. Hartatik and Ismoyowati. 2013a. Polymorpishm of Dloop mitochondrial and phylogenetic in five indonesian native duck population. Int. J. Poult. Sci. 12(1):55-63.

Purwantini, D., T. Yuwanta., T. Hartatik, and Ismoyowati. 2013b. Morphology and genetic diversity of mitochondrial DNA Dloop region using PCR-RFLP analysis in magelang duck and other native duck. J. Indonesian Trop. Anim. Agric. 38(1):1-9.

Rich, P.R. and A. Maréchal. 2010. The mitochondrial respiratory chain. Essay Biochemistry. 47:1-23.

$\mathrm{Su}$, Y., C.W. Liu, L. Liu, C.H. Ye, W.Q. Cao, Y.Q. Huang, J. Zheng, D.Y. Cail, and O. Olowofeso. 2006. Studies on genetic variation of different chinese duck populations with random amplified polymorphic DNA analysis. Asian-Aust. J. Anim. Sci. 19(4):475-481

Sudewo, A.T.A. 2005. Analisis pola protein globulin darah untuk menduga jarak genetik antar populasi Itik Tegal, Magelang, dan Mojosari. Animal Production. 7(3):177-184.

Sultana, H., D.W. Seo, M.S.A. Bhuiyan, N.R. Choi, M.R. Hoque, K.N. Heo, and J.H. Lee. 2016. Genetic diversity and phylogenetic analysis of south-east asian duck population based on the mtdna D-loop sequences. J. Anim. Sci. 29(12): 1688-1695.

Suryo. 2005. Genetika. Cetakan Ke-1. Gadjah Mada University Press. Yogyakarta.

Szwaczkowski T., M. Grzech, A. Borowska, E. Wencek, and A. Wolck. 2010. Maternal genetic effects on body weight and breast morphological traits in duck population under selection. Archiv Tierzucht. 53(3): 600-608.

Tamura, K., G. Stecher, D. Peterson, A. Filipski, and S. Kumar. 2013. MEGA6: Molecular evolutionary genetics analysis version 6.0. Mol. Bio. Evol. 30:2725-2729.

Teguia, A., H.M. Ngandjou, H. Defang, and J. Tchoumboue. 2008. Study of the live body weight and body characteristics of the african Muscovy Duck (Cairina moschata). Trop. Anim. Health Prod. 40:5-10.

Warwick, E.J., J.M. Astuti and W. Hardjosubroto. 1995. Pemuliaan Ternak. Edisi 5. Gadjah Mada University Press. Yogyakarta.

Wu, Y., X. Liu, S. Hou, and W. Huang. 2008. 
Study on genetic diversity of six duck populations with microsatellite DNA. AsianAust. J. Anim. Sci. 21(6):776-783.

Yakubu and S.B. Ugbo. 2011. An assessment of biodiversity in morphological traits of muscovy ducks in Nigeria using discriminant analysis. Int. Conf. Biol. Envi. Chem. IPCBEE. 1:389-391. 